\title{
PHYSICAL PROPERTIES OF DIFFERENT SOYBEAN CULTIVARS DURING DRYING
}

\author{
Michele R. Hauth ${ }^{1 *}$, Fernando M. Botelho², Renata H. Hoscher ${ }^{3}$, Sílvia de C. C. Botelho4, \\ Gabriel H. H. de Oliveira ${ }^{5}$
}

${ }^{1 *}$ Corresponding author. Federal University of Grande Dourados/ Dourados - MS, Brazil. E-mail: michele.r.hauth@hotmail.com

\section{KEYWORDS}

Glycine $\max (\mathrm{L}$.$) ,$ moisture content, physical characteristics, shape and size.

\begin{abstract}
The knowledge of physical properties of grains is important for the optimization of postharvest operations. Thus, this study aimed to evaluate the effect of moisture content over physical properties of different cultivars of soybean. Soybean of cultivars NS7901RR, TMG1180RR, P98Y70 and TMG132RR were used, with initial moisture content of $0.32,0.27,0.25$ and 0.21 dry basis (d.b.), respectively. In order to dry the samples, an oven of forced air circulation was used. Samples were dried at temperature of $50{ }^{\circ} \mathrm{C}$, being the drying procedure stopped when the moisture content of soybean was equal or inferior than 0.15 (d.b.). During drying, for interested moisture contents, physical properties were determined: bulk density, equivalent diameter, sphericity, circularity and surface/volume ratio. It was noticed that all physical properties analyzed presented a direct relationship with moisture content. With exception of the equivalent diameter, all the remaining physical properties increased linearly with moisture content reduction. Physical differences were observed among soybean cultivars during drying. However, variation of analyzed properties occurred in different proportions during drying for each cultivar.
\end{abstract}

\section{INTRODUCTION}

Soybean, Glycine max (L.) Merrill is an important commodity in the Brazilian agricultural scenario. Valorization of this product is associated, among other factors, by its different use in the industry due to its chemical composition, in other words, is a product that possess elevated contents of oil and protein, around $20 \%$ and $40 \%$, respectively.

Foodstuff consumer has been more demanding of quality in the final product. Thus, in the case of grain and cereals, is mandatory that production and processing stages are accomplished adequately, aiming to preserve qualitative attributes of the product.

Being that stated, drying is the most used method to assure final product quality, since it reduces the amount of water present in the material, thus decreasing its biological activity and chemical and physical changes that may occur during storage (Corrêa et al., 2007). Berbert et al. (2008) emphasizes that moisture content is one of the factor that are more significant in the prevention of grain deterioration, in which maintaining low both moisture content and temperature of the product, microorganism's incidence and respiration rate of the grain are minimized.
However, if poorly conducted, drying may affect negatively the quality of the product due to, mainly, temperature and relative humidity conditions, which generates elevated rates of water removal (Resende et al., 2012). Drying allows the removal of water from the product, but, parallelly, this process causes damages at the cellular structures of the product, leading to shape changes and decrease in its characteristics dimensions (Mayor \& Sereno, 2004).

Moisture is the variable that most affects the physical properties of agricultural products, as observed by Araujo et al., (2015), Araujo et al., (2014), Oliveira et al., (2013), among others. Along with moisture content, other variables also impact the physical properties, such as drying air temperature (Coradi et al., 2015; Oliveira et al., 2010), and seeding period (Bornhofen et al., 2015). Physical properties of grain and cereals have direct application on quality evaluation or optimization and development of machinery used in grain handling, from seeding until storage.

Therefore, it is essential to know the physical properties of this products and the factor that affects it. Goneli et al. (2011) stated that the knowledge of physical

\footnotetext{
${ }^{2}$ Federal University of Mato Grosso/ Sinop - MT, Brazil.

${ }^{3}$ Federal University of Grande Dourados/ Dourados - MS, Brazil.

${ }^{4}$ Embrapa Agrossilvipastoral/ Sinop - MT, Brazil.

${ }^{5}$ Federal Institute of Education, Science and Technology of the Southeast of Minas Gerais/ Realeza District, Manhuaçu - MG, Brazil. Received in: 8-14-2017
} 
properties, during drying, is also relevant for the correct post-harvest management. Information about size, volume, porosity, density and others are basic information for projection and monitoring of drying and storage of several agricultural products.

Being that stated, the objective of this study is to evaluate the effect of moisture content variation over the physical properties of different soybean cultivars.

\section{MATERIAL AND METHODS}

Soybean of cultivars NS7901RR, TMG1180RR, P98Y70 and TMG132RR were used. These are cultivars with expected cycles of $110,115,120$ and 133 days, respectively. Cultivars were cultivated according to traditional techniques at the first harvest of the year 2014/2015 at farms located in Sinop city, MT.

Initially grain was cleaned and selected; the damaged ones and all kind of strange materials have been removed. Soybean grains from cultivars NS7901RR, TMG1180RR, P98Y70 and TMG132RR presented an initial moisture content of $0.32,0.27,0.21$ and 0.25 dry basis (d.b.), respectively. Moisture content was determined using the oven method at $105 \pm 1^{\circ} \mathrm{C}$ during $24 \mathrm{~h}$, with three repetitions (Brasil, 2009).

Grains were submitted to drying in an oven with air forced circulation, set at temperature of $50^{\circ} \mathrm{C}$. Drying was made in perforated trays of galvanized plates $(\varnothing=2.5$ $\mathrm{mm}$ ), with average dimensions of $320 \times 260 \times 50 \mathrm{~mm}$, with $750 \mathrm{~g}$ of grain in each tray. Monitoring of this process was made by mass difference, knowing the initial moisture content of the product. Drying was interrupted when samples reached a moisture content of 0.15 (d.b.) or lower.

The mass of samples was obtained by means of an analytical scale with $0.01 \mathrm{~g}$ of resolution. During the process, at moisture content of interest, drying was interrupted and physical properties were determined.

Bulk density $\left(\rho_{\text {ap }}\right)$ was determined with the relationship between the mass and volume of grains, measured in a graduated cylinder with a volume of 1000 $\mathrm{mL}$. During drying, the soybean was put in the cylinder, in which were read the volume of the grain mass, and afterwards, grain mass was weighed with the aid of an analytical scale with $0.01 \mathrm{~g}$ of resolution. This procedure was made for each moisture content and each cultivar, with two repetitions.

For shape determination, 12 soybean grains of each cultivar were selected and dried in separate. During drying, mass and main dimensions were determined, as illustrated in Figure 1. Main dimension characteristics of these grains were made with a digital caliper with resolution of 0.01 $\mathrm{mm}$. The mass of each grain was weighed with the aid of an analytical scale with $0.01 \mathrm{~g}$ of resolution.

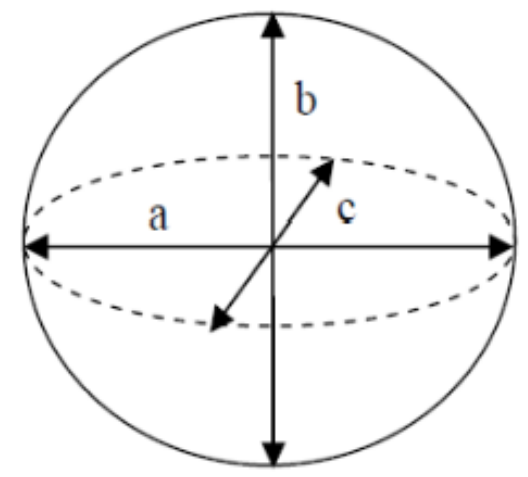

FIGURE 1. Schematic draw of a soybean, in which "a", " $b$ " and "c" are the highest, the average and the lowest characteristic dimension, respectively.

The equivalent diameter $\left(D_{e}\right)$, which corresponds to the mean dimension, was determined by [eq. (1)].

$$
\mathrm{D}_{\mathrm{e}}=(\mathrm{abc})^{\frac{1}{3}}
$$

in which,

$\mathrm{D}_{\mathrm{e}}$ - equivalent diameter of soybean, $\mathrm{mm}$;

a - the highest characteristic dimension of soybean, mm;

b - the average characteristic dimension of soybean, $\mathrm{mm}$, and

$\mathrm{c}$ - the lowest characteristic dimension of soybean, $\mathrm{mm}$.

The sphericity of the soybean grains $(\phi)$ was accomplished by [eq. (2)].

$$
\phi=\frac{\mathrm{De}}{\mathrm{a}} \times 100=\frac{\sqrt[3]{\mathrm{abc}}}{\mathrm{a}} \times 100
$$

in which,

$$
\phi \text { - sphericity, } \% \text {. }
$$

Circularities of soybean grains $\left(\mathrm{C}_{\mathrm{x}}\right)$ were calculated for the three dimensions of soybean into a plan, in other words, projection of the highest dimension $\left(\mathrm{C}_{1}\right)$, the average dimension $\left(C_{2}\right)$ and the lowest dimension $\left(C_{3}\right)$, according to [eq. (3)].

$$
C_{x}=\left[\frac{D_{i}}{D_{c}}\right] \times 100
$$

in which,
$\mathrm{C}_{\mathrm{x}}$ - circularity for the projection of dimension " $\mathrm{x}$ ", \%;
$\mathrm{D}_{\mathrm{i}}$ - diameter of the highest inscribed circle at the product, $\mathrm{mm}$, and
$\mathrm{D}_{\mathrm{c}}$ - diameter of the lowest inscribed circle at the product $\mathrm{mm}$. 
In order to obtain the volume and superficial area, required to calculate the surface-volume ratio (SV), it was assumed that soybean grains (Figure 1) have a shape approximated to a scalene triaxial spheroid. Soybean volume was obtained by [eq. (4)].

$$
\mathrm{V}_{\mathrm{g}}=\frac{\pi}{6}(\mathrm{a} \mathrm{b} \mathrm{c})
$$

in which,

$$
\mathrm{V}_{\mathrm{g}} \text { - soybean volume, } \mathrm{mm}^{3} \text {. }
$$

Superficial area (S) was calculated according to [eq. (5)], known as Knud Thomsen's (Mele et al., 2016). Knud Thomsen's equation, used as constant ' $z$ ", results in a maximum error of $1.061 \%$ in the estimation of superficial area of the spheroid.

$$
\mathrm{S}=4 \pi\left[\frac{\left(\frac{\mathrm{a}}{2}\right)^{\mathrm{z}}\left(\frac{\mathrm{b}}{2}\right)^{\mathrm{z}}+\left(\frac{\mathrm{a}}{2}\right)^{\mathrm{z}}\left(\frac{\mathrm{c}}{2}\right)^{\mathrm{z}}+\left(\frac{\mathrm{c}}{2}\right)^{\mathrm{z}}\left(\frac{\mathrm{b}}{2}\right)^{\mathrm{z}}}{3}\right]^{\frac{1}{\mathrm{Z}}}
$$

in which,

$\mathrm{S}$ - superficial area, $\mathrm{mm}^{2}$, and

$\mathrm{Z}$ - approximation constant equivalent to 1.6075 .
The surface-volume relationship of soybean grains was calculated by [eq. (6)].

$$
\mathrm{SV}=\frac{\mathrm{S}}{\mathrm{V}_{\mathrm{g}}}
$$

in which:

$\mathrm{SV}$ - surface-volume ratio, $\mathrm{mm}^{-1}$.

Experimental data of physical properties were submitted to analysis of variance followed by linear regression, being selected the mathematical model more adequate to express the relationship among these physical characteristics and the soybean moisture content. The adjustment degree of the coefficients of each model was evaluated by the " $\mathrm{t}$ " test, with significance level of $5 \%$ of probability.

\section{RESULTS AND DISCUSSION}

Figure 2 presents the experimental and estimated values of bulk density of the soybean grains of the analyzed cultivars, for different moisture contents.

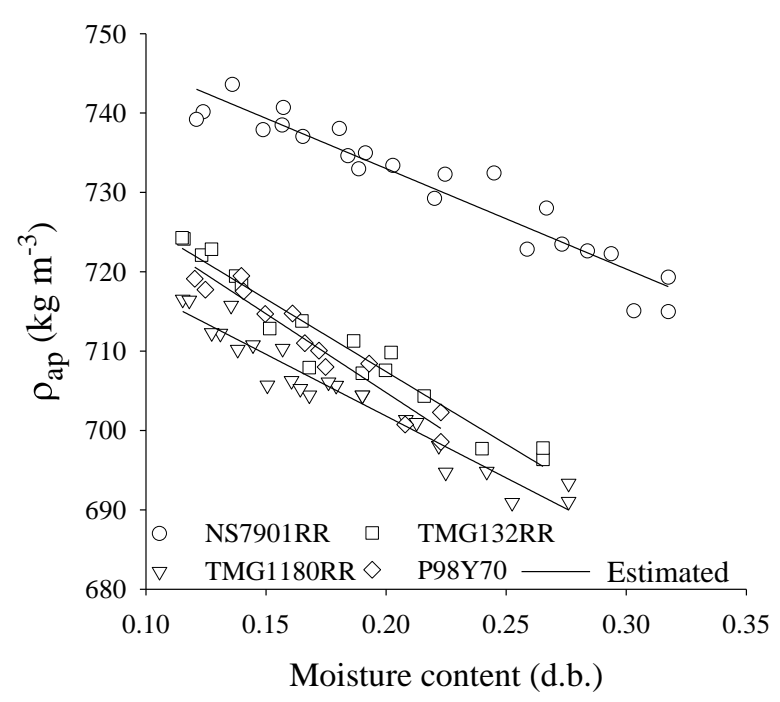

$$
\begin{array}{rrrr}
\mathrm{d}=758.32-126.59^{*} \mathrm{U} & \nabla=744.01-182.96^{*} \mathrm{U} & \mathrm{W}=744.47-198.43^{*} \mathrm{U} & \diamond=732.96-155.71^{*} \mathrm{U} \\
\mathrm{R}^{2}(\%)=95.6 & \mathrm{R}^{2}(\%)=97.3 & \mathrm{R}^{2}(\%)=96.5 & \mathrm{R}^{2}(\%)=96.7
\end{array}
$$

${ }^{*}$ ) Significant by the " $\mathrm{t}$ " test: $p$-value $<0.0001$

FIGURE 2. Observed and estimated values of bulk density as a function of moisture content throughout drying for different soybean cultivars.

It was observed that bulk density of soybean grains, independently of the cultivar analyzed, increased linearly with moisture content reduction. Linear dependences of density with moisture content are frequently observed during drying of different agricultural products, such as beans (Resende et al., 2008) and soybean (Wandkar et al., 2012), which presented an increment of this property, and for paddy rice (Zareiforoush et al., 2009) and sunflower
(Figueiredo et al., 2011), that bulk density decreased with moisture content reduction.

Experimental values of bulk density of soybean varied between 691 and $739 \mathrm{~kg} \mathrm{~m}^{-3}$ for a moisture content range of 0.32 to 0.12 (d.b.). These values are higher than the results reported by Alencar et al. (2009) and similar to the values reported by Botelho et al. (2015) and Wandkar et al. (2012). 
Bulk density is one of the main physical properties used to evaluate the products quality. For the entire range of moisture content studied, there were differences between cultivars, being the cultivar NS7901RR the one that presented the highest values of bulk density, followed by TMG132RR, P98Y70 and TMG1180RR cultivars. One important factor is that the cultivation conditions may affect the quality of the cultivar performance.
Soybean bulk density dependence on moisture content (Figure 2), for all cultivars studied, was satisfactory represented ( $p$-value $<0.0001$ ) by a first degree polynomial equation, based on elevated determination coefficients $\left(R^{2}>95.0 \%\right)$.

Figure 3 presents the observed and estimated values of equivalent diameter of soybean grains for the studied cultivars as a function of moisture content.

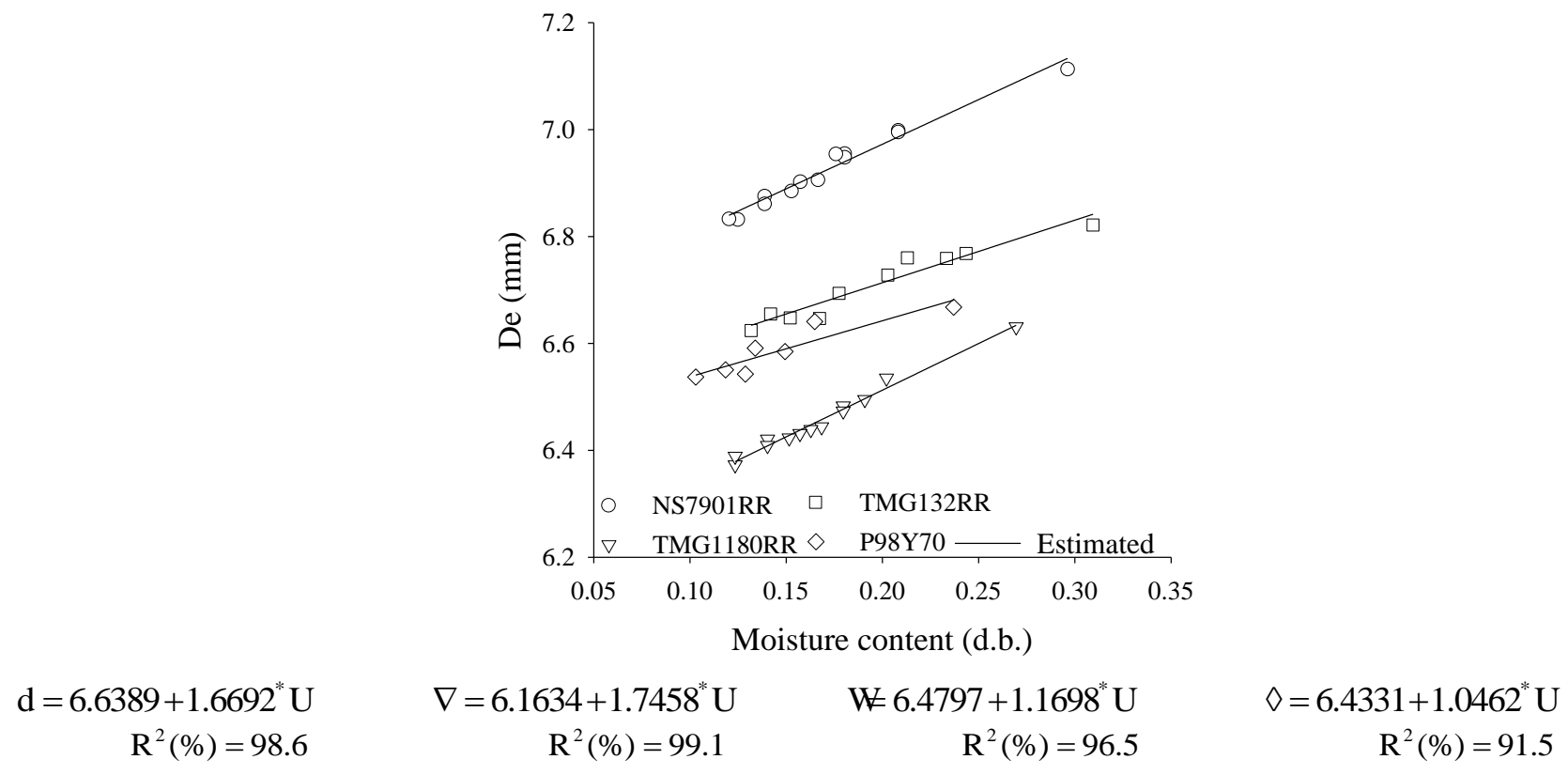

(")Significant by the " $\mathrm{t}$ " test: $p$-value $<0.0038$

FIGURE 3. Observed and estimated values of equivalent diameter as a function of moisture content throughout drying for different soybean cultivars.

It can be noticed that the equivalent diameter of soybean continuously decreased and it is proportional to moisture content reduction throughout drying process for all cultivars analyzed. This trend was also observed by Goneli et al. (2011), Wandkar et al. (2012) and Araujo et al. (2014) for castor fruits, soybeans and peanut grain, respectively.

Equivalent diameter (or geometric diameter) reflects, in the case of soybean, the average size of the grain, allowing the characterization of the studied cultivars by this property. It can be said that cultivar NS7901RR, is the one that has bigger grain, whilst P98Y70 is the cultivar with lower size of grain, independently of the moisture content. However, observing the slope of the adjusted equations, the same cultivars were the ones that presented higher variations of equivalent diameter throughout drying (Figure 3). This can be an indicator that the average size of grains is directly related to the reduction of its characteristics dimensions during drying.

Decrease of the products size is due to the reduction of its dimensions by loss of water, being such phenomenon denominated as volumetric shrinkage, which is observed for most agricultural products, among them, fig (Corrêa Filho et al., 2015), banana (Leite et al., 2015), beans (Oliveira et al., 2014) and soybeans (Oliveira et al., 2013; Smaniotto et al., 2015). Starting from the reduction of characteristics dimensions, dryer's designers may improve and/or design drying systems, more efficient, considering factors such as air flow direction, product movement in the dryer, among other parameters and processes (Araujo et al., 2015).

Observed and estimated values of sphericity of soybean grains in function of moisture content throughout drying are presented in Figure 4. 


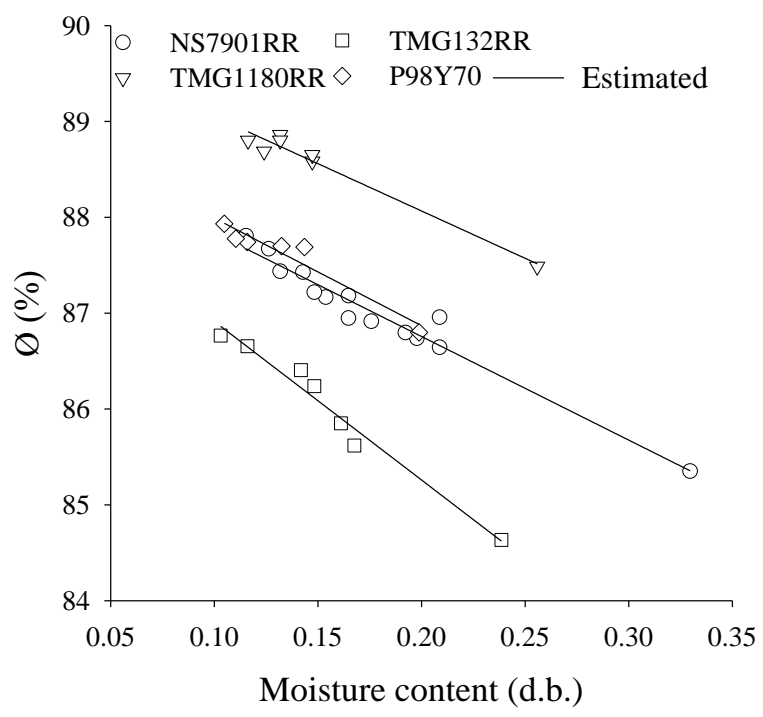

$$
\begin{array}{cccc}
\mathrm{d}=88.9192-10.8146^{*} \mathrm{U} & \nabla=90.0414-9.8775^{*} \mathrm{U} & \mathrm{W} 88.5682-16.5456^{*} \mathrm{U} & \diamond=89.1147-11.2282^{*} \mathrm{U} \\
\mathrm{R}^{2}(\%)=97.8 & \mathrm{R}^{2}(\%)=98.2 & \mathrm{R}^{2}(\%)=98.6 & \mathrm{R}^{2}(\%)=96.2
\end{array}
$$

(")Significant by the " $\mathrm{t}$ " test: $p$-value $<0.0022$

FIGURE 4. Observed and estimated values of sphericity as a function of moisture content throughout drying for different soybean cultivars.

By means of Figure 4, it can be noticed that similar to bulk density, sphericity of soybean grains, regardless of the cultivar, increased their values during drying, thus presenting an inverse relationship with moisture content reduction.

It can be verified that occurred differences regarding the proportion that this property varied during drying, when cultivars are compared. Cultivar TMG1180RR presented higher values of sphericity, followed by cultivars P98Y70, NS7901RR and TMG132RR. However, magnitudes of this variation during drying occurred differently among cultivars, in other words, cultivar TMG132RR presented higher variation, whilst cultivars P98Y770, NS7901RR and TMG1180RR varied in a lower proportion, but similar between them (Figure 4).

Sphericity is an index that determines how much the product with a certain shape approximates to a sphere. Thus, studies of the variations that may occur regarding this and others physical properties related to size and shape of the product, are required because it demonstrates the importance of these parameters to recommend discs for plantation and sieves for processing. This enables optimization of the equipment, reducing percentage of break loss and product damage during stages of plantation, harvest and post-harvest.

Values of sphericity, for the cultivars studied, varied between 84.6 and $88.8 \%$ for moisture content range from 0.33 to 0.10 (d.b.), proving elevated sphericity usually observed for soybeans grains. Similar values were reported by Tavakoli et al. (2009) and Shirkole et al. (2011) studying the dependence of physical properties of soybean grains with moisture content.

Figures 5, 6 and 7 presents the observed and estimated values of circularity for the projection of the highest dimension $\left(\mathrm{C}_{1}\right)$, the average dimension $\left(\mathrm{C}_{2}\right)$ and the lowest dimension $\left(\mathrm{C}_{3}\right)$ of soybean grains as a function of moisture content. 


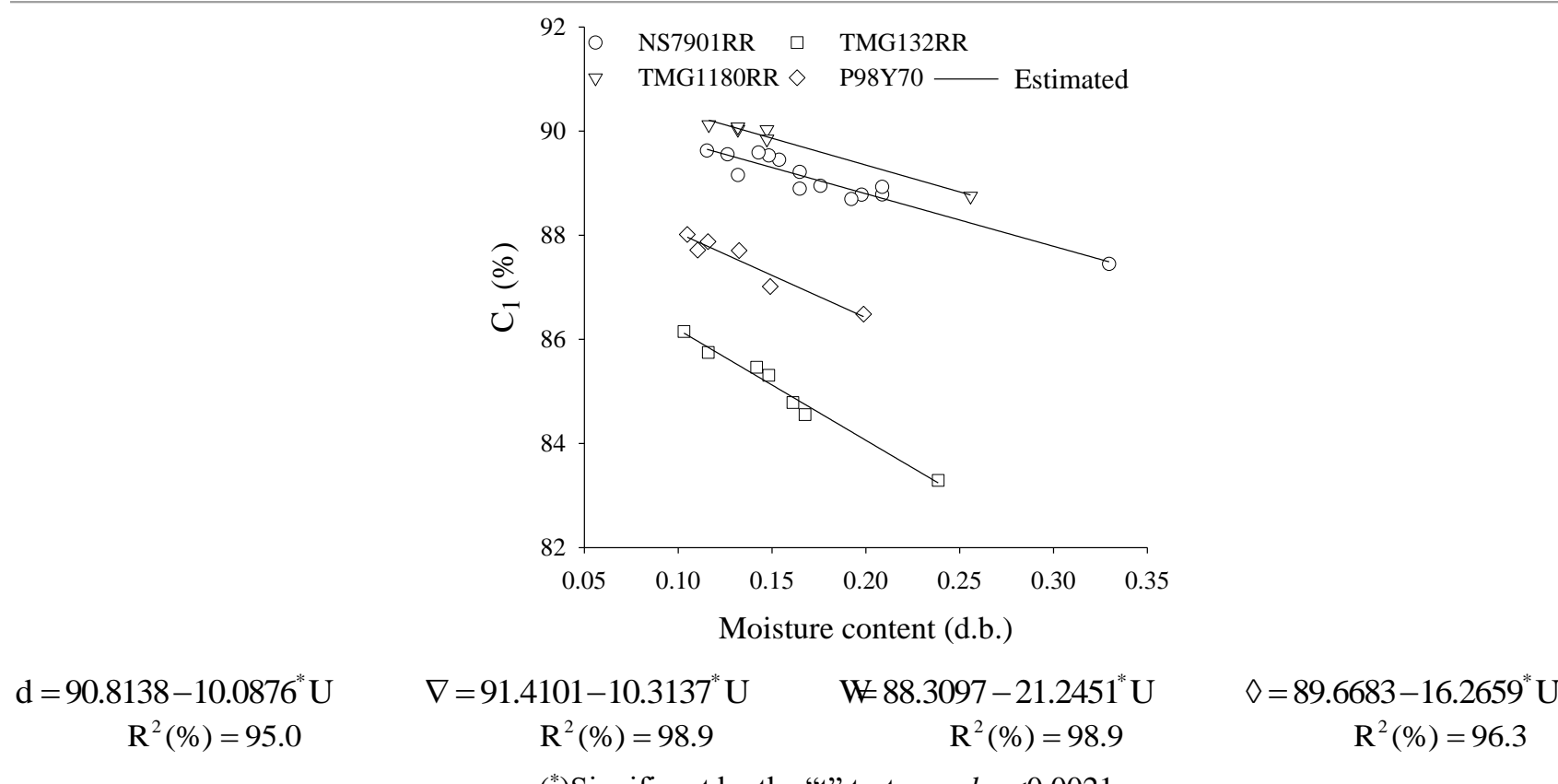

$\left(^{*}\right)$ Significant by the " $\mathrm{t}$ " test: $p$-value $<0.0021$

FIGURE 5. Observed and estimated values of circularity for the projection of the highest dimension $\left(\mathrm{C}_{1}\right)$ of soybean as a function of moisture content for different cultivars.

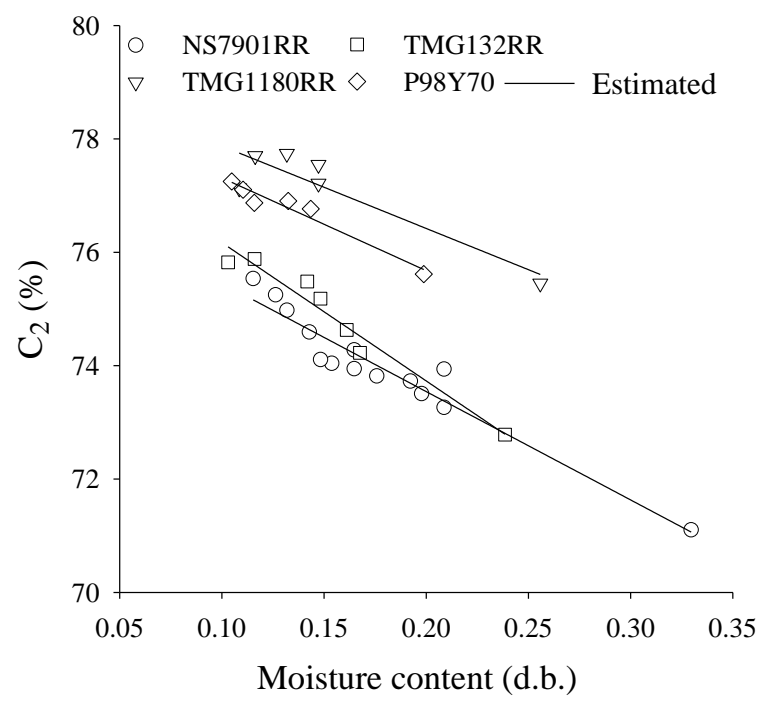

$$
\begin{array}{cccc}
\mathrm{d}=77.3649-19.1113^{*} \mathrm{U} & \nabla=79.3281-14.5395^{*} \mathrm{U} & \mathrm{W} 78.6120-24.4074^{*} \mathrm{U} & \diamond=78.9510-16.3764^{*} \mathrm{U} \\
\mathrm{R}^{2}(\%)=96.4 & \mathrm{R}^{2}(\%)=90.8 & \mathrm{R}^{2}(\%)=97.7 & \mathrm{R}^{2}(\%)=97.5
\end{array}
$$

(*)Significant by the " $\mathrm{t}$ " test: $p$-value $<0.0124$

FIGURE 6. Observed and estimated values of circularity for the projection of the average dimension (C2) of soybean as a function of moisture content for different cultivars. 


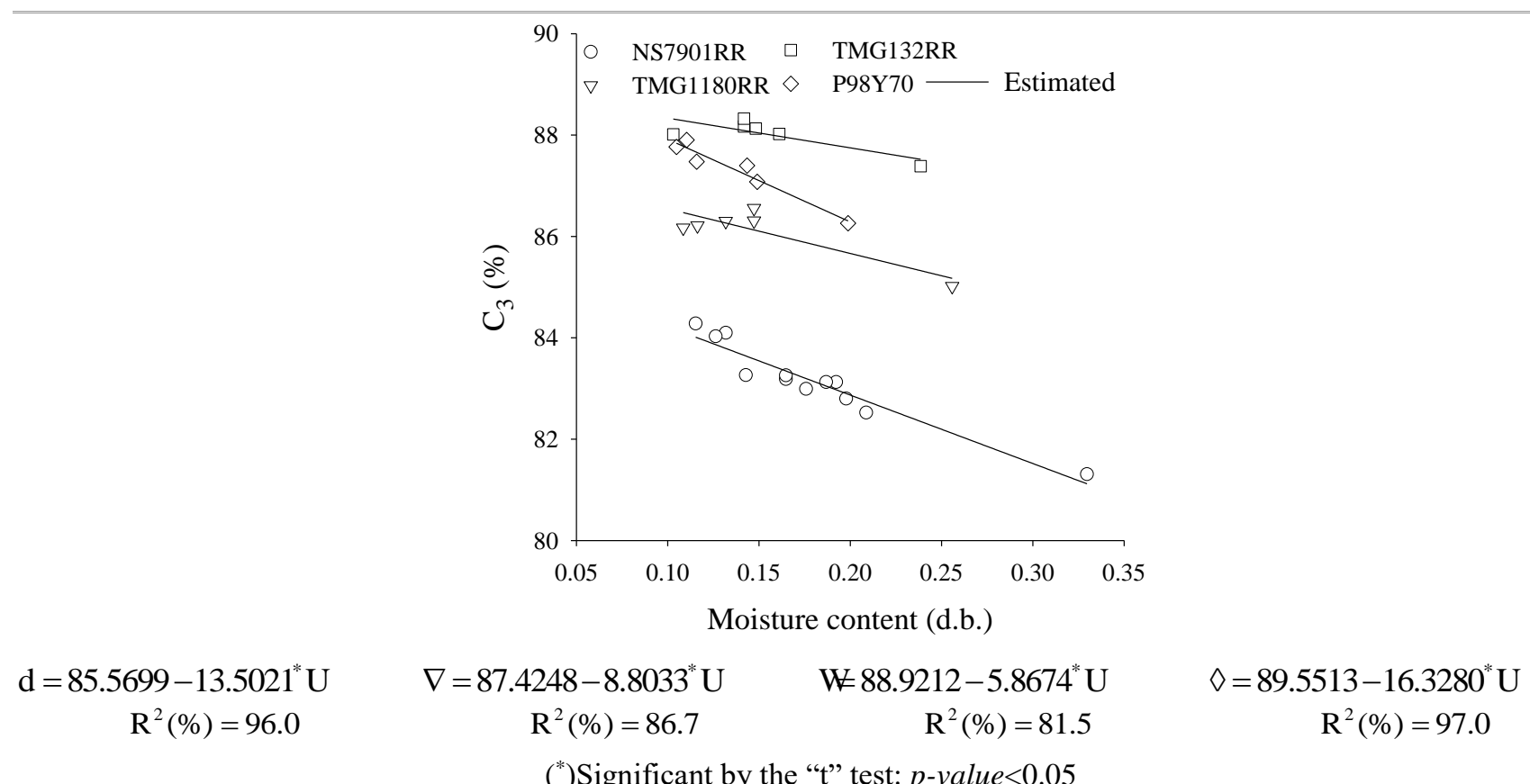

FIGURE 7. Observed and estimated values of circularity for the projection of the lowest dimension $\left(C_{3}\right)$ of soybean as a function of moisture content for different cultivars.

It can be noticed, from Figures 5, 6 and 7 that circularities $\mathrm{C}_{1}, \mathrm{C}_{2}$ and $\mathrm{C}_{3}$ of soybean grains for all cultivars, presented similar trend as sphericity data (Figure 4 ), in other words, increased linearly with reduction of moisture content.

Cultivar TMG132RR presented higher variation for circularities $C_{1}$ and $C_{2}$, whilst cultivars NS7901RR and TMG1180RR presented lower variation for respective circularities (Figure 5 and Figure 6). Cultivars P98Y70 and TMG132RR presented, respectively, higher and lower variation for circularity $\mathrm{C}_{3}$ (Figure 7). It can be observed that cultivar P98Y70 presented the most homogeneous variation among their circularities, indicating that the variation of the characteristics dimensions was uniform during drying.

Thus, it can be concluded that there are differences regarding circularity during drying when the cultivars are compared. This result, such as the remaining found at the present study, reinforces that continuous studies are required in order to evaluate the physical properties, aiming not only the product itself, but also the genetic singularities potentiated by varietal characteristic.
Circularities $\left(\mathrm{C}_{1}, \mathrm{C}_{2}\right.$ and $\left.\mathrm{C}_{3}\right)$ varied in different proportions as a function of moisture content due to uninform reductions of their principal characteristics dimensions (Figure 1). This trend is observed for most of agricultural products throughout drying, such as chickpeas (Eissa et al., 2010), soybean (Shirkole et al., 2011), coffee (Botelho et al., 2016), among others.

At the present study, both sphericity and circularities increased with decrease of moisture content. This trend was also observed by Siqueira et al. (2012), working with jatropha. Araujo et al. (2015), Botelho et al. (2016) and Coradi et al. (2015), working with peanuts, coffee and sunflower, respectively, did not observed this trend.

For the moisture content range in which were observed variations of circularities, for all cultivars, were adjusted polynomial equations of first order, which described significantly ( $p$-value $<0.05)$ the dependence of these variables by moisture content (Figure 5, 6 and 7).

Figure 8 presents the observed and estimated values of the surface-volume relationship of soybean grains for the cultivars studied throughout drying. 


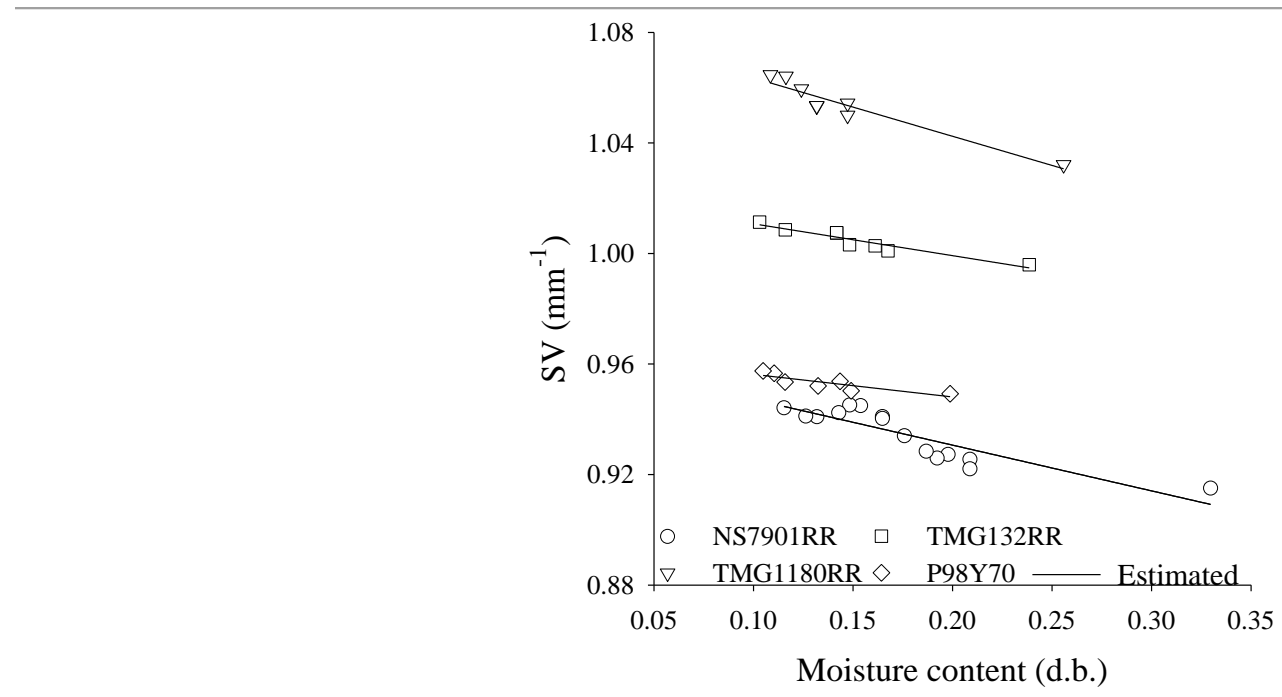

$$
\begin{array}{rrrr}
\mathrm{d}=0.9637-0.1655^{*} \mathrm{U} & \nabla=1.0846-0.2109^{*} \mathrm{U} & \mathrm{W}=0.9644-0.0818^{*} \mathrm{U} & \diamond=1.0222-0.1151^{*} \mathrm{U} \\
\mathrm{R}^{2}(\%)=88.1 & \mathrm{R}^{2}(\%)=95.5 & \mathrm{R}^{2}(\%)=85.9 & \mathrm{R}^{2}(\%)=95.2
\end{array}
$$

$\left.{ }^{*}\right)$ Significant by the " $\mathrm{t}$ " test: $p$-value $<0.0132$

FIGURE 8. Observed and estimated values of surface-volume ratio as a function of moisture content during drying for different soybeans cultivars.

It can be observed that the values of surface-volume relationship increased, regardless of the cultivar, in a linear way with the decrease of moisture content (Figure 8). Cultivar TMG1180RR presented higher values of surfacevolume relationship and higher variation for this property, followed by TMG132RR, P98Y70 and NS7901RR with lower values, and cultivar TMG132RR with lower variation.

Usually, for most agricultural products, both superficial area and volume decrease with moisture content decrease, as reported by Tavakoli et al. (2009), Siqueira et al. (2012), Araujo et al. (2015) and Coradi et al. (2015). Such physical properties are dependent, basically, by its principal dimension characteristics of the product. Thus, disproportionality in which these physical properties vary is the explanation for the tendency of the surfacevolume relationship of soybean grains during drying, in other words, volume of soybean grains varied in a lower proportion than its superficial area.

Evaluation of this property is extremely important for drying studies, because the higher surface-volume relationship of a certain product, easier will be the heat and mass transfer (Botelho et al., 2015).

As reported previously for other physical properties, dependence of this variable with moisture content was satisfactory described by a polynomial model of first order ( $p$-value < 0.0132) (Figure 8).

\section{CONCLUSIONS}

All physical properties analyzed presented a direct relationship with moisture content. With the exception of equivalent diameter, remaining physical properties (bulk density, sphericity, circularity and surface-volume relationship) increased linearly with moisture content decrease.

Physical differences between cultivars were kept for all properties analyzed, however, variation during drying occurred in different proportions.

\section{REFERENCES}

Alencar ER, Faroni LRD, Lacerda Filho AF, Peternelli LA, Costa AR (2009) Qualidade dos grãos de soja armazenados em diferentes condições. Revista Brasileira de Engenharia Agrícola e Ambiental 13(5):606-613.

Araujo WD, Goneli ALD, Souza CMA, Gonçalves AA, Vilhasanti HCB (2014) Propriedades físicas dos grãos de amendoim durante a secagem. Revista Brasileira de Engenharia Agrícola e Ambiental 18(3):279-286.

Araujo WD, Goneli ALD, Orlando RC, Martins EAS, Hartmann Filho CP (2015) Propriedades físicas dos frutos de amendoim durante a secagem. Revista Caatinga 28(4):170-180. DOI: http://dx.doi.org/10.1590/1983$21252015 \mathrm{v} 28 \mathrm{n} 419 \mathrm{rc}$

Brasil (2009) Ministério da Agricultura, Pecuária e Abastecimento. Secretaria de Defesa Agropecuária. Regra para análise de sementes. Brasília: Mapa/ACS, 399 p.

Berbert PA, Silva JS, Ruffato S, Afonso ADL (2008) Indicadores da qualidade dos Grãos. In: Silva JS. Secagem e armazenagem de produtos agrícolas. Editora Aprenda Fácil, p 63-107.

Bornhofen E, Benin G, Galvan D, Flores MF (2015) Épocas de semeadura e desempenho qualitativo de sementes de soja. Pesquisa Agropecuária Tropical 45(1):46-55.

Botelho FM, Granella SJ, Botelho SCC, Garcia TRB (2015) Influência da temperatura de secagem sobre as propriedades físicas dos grãos de soja. Engenharia na Agricultura 23(3):212-219.

Botelho FM, Correa PC, Botelho SCC, Vargas-Elias GA, Almeida MDSD, Oliveira GHH (2016) Propriedades físicas de frutos de café robusta durante a secagem: determinação e modelagem. Coffee Science 11(1):65-75. 
Coradi PC, Helmich JC, Fernandes CHP (2015) Alterações físicas em grãos de girassol após secagem com diferentes temperaturas do ar. Nucleus 12(2):201-210. DOI: http://dx.doi.org/10.3738/1982.2278.1502

Corrêa Filho LC, Andrade ET, Martinazzo AP, D'Andrea EM, Sousa FA, Figueira VG (2015) Cinética de secagem, contração volumétrica e análise de difusão líquida do figo (Ficuscarica L.). Revista Brasileira de Engenharia Agrícola e Ambiental 19(8):797-802. DOI: http://dx.doi.org/10.1590/1807-1929/agriambi.v19n8p797802

Corrêa PC, Resende O, Martinazzo AP, Goneli ALD, Botelho FM (2007) Modelagem matemática para a descrição do processo de secagem do feijão (Phaseolus vulgaris L.) em camadas delgadas. Revista de Engenharia Agrícola 27(2):501-510.

Eissa AHA, Mohamed MA, Moustafa H, Abdul ROA (2010) Moisture dependent physical and mechanical properties of chickpea seeds. International Journal Agricultural \& Biological Engineering 3(4):80-93.

Figueiredo AK, Baumler E, Riccobene IC, Nolasco SM (2011) Moisture dependent engineering properties of sunflower seeds with different structural characteristics. Journal of Food Engineering 102(1):58-65. DOI: http://dx.doi.org/10.1016/j.jfoodeng.2010.08.003

Goneli ALD, Corrêa PC, Magalhães FEA, Baptestini FM (2011) Contração volumétrica e forma dos frutos de mamona durante a secagem. Acta Scientiarum Agronomy 33(1):1-8. DOI:

http://dx.doi.org/10.4025/actasciagron.v33i1.4629

Leite ALMP, Silva FS, Porto AG, Piasson D, Santos P (2015) Contração volumétrica e cinética de secagem de fatias de banana variedade Terra. Pesquisa Agropecuária Tropical, 45(2): 155-162. DOI: 10.1590/1983$40632015 \mathrm{v} 4530270$

Mayor L, Sereno AM (2004) Modelling shrink age during convective drying of food materials: a review. Journal of Food Engineering 61:373-386. DOI: http://dx.doi.org/10.1016/S0260-8774(03)00144-4

Mele D, Dellino P, Sulpizio R, Braia G (2011) A systematic investigation on the aerodynamic sofash particles. Journal of Volcanology and Geothermal Research 203:1-11. DOI:

http://dx.doi.org/10.1016/j.jvolgeores.2011.04.004

Oliveira LC, Gutkoski LC, Elias MC, Mazzutti S, Aosani E, Rocha JC (2010) Efeito da temperatura de secagem na qualidade de grãos de aveia branca. Ciência e Agrotecnologia 34(2):313-319.
Oliveira DEC, Resende O, Mendes UC, Smaniotto TAS, Donadon JR (2014) Modelagem da contração volumétrica do feijão-adzuki durante a secagem. Científica 42(1):2331.

Oliveira DEC, Resende O, Smaniotto TAS, Siqueira VC, José Neto CA (2013) Alterações morfométricas em grãos de soja durante o processo de secagem. Ciências Agrárias 34(3):975-984. DOI: http://dx.doi.org/10.5433/1679$0359.2013 v 34 n 3 p 975$

Resende O, Corrêa PC, Goneli ALD, Ribeiro D M (2008) Propriedades físicas do feijão durante a secagem: determinação e modelagem. Ciência e Agrotecnologia 32(1):225-230.

Resende O, Almeida DP, Costa LM, Mendes UC, Sales JF (2012) Adzuki beans (Vigna Angularis) seed quality under several drying conditions. Ciência e Tecnologia de Alimentos 32(1):151-155.

Shirkole SS, Kenghe RN, Nimkar PM (2011) Moisture dependent physical properties of soybean. International Journal of Engineering Science and Technology 3(5):3807-3815.

Siqueira VC, Resende O, Chaves TH, Soares FAL (2012) Forma e tamanho dos frutos de pinhão-manso durante a secagem em cinco condições de ar. Revista Brasileira de Engenharia Agrícola e Ambiental 16(8):864-870.

Smaniotto TAS, Resende O, Oliveira DEC, Siqueira VC, Sousa KA (2015) Ajuste de modelos matemáticos a contração volumétrica unitária e da massa dos grãos de soja. Revista Agro@mbiente On-line 9(4):397-404. DOI: http://dx.doi.org/10.18227/1982-8470ragro.v9i4.2565

Tavakoli H, Rajabipour A, Mohtasebi SS (2009) Moisture dependente some engineering properties of soybean grains. Agricultural Engineering International: the CIGR Ejournal 6:1110-1124.

Wandkar SV, Ukey PD, Pawar DA (2012) Determination of physical properties of soybean at different moisture levels. Agricultural Engineering International 14(2):138142.

Zareiforoush H, Komarizadeh MH, Alizadeh MR (2009) Effect of moisture content on some physical properties of paddy grains. Research Journal of Applied Sciences, Engineering and Technology 1(3):132-139. 